\title{
What's New in Shona Street Lingo? Semantic Change in Lingo Adoptives from Mainstream Shona
}

\author{
Shumirai Nyota ${ }^{1} \&$ Rugare Mareva ${ }^{1}$ \\ ${ }^{1}$ Great Zimbabwe University, Masvingo, Zimbabwe \\ Correspondence: Rugare Mareva, Department of Curriculum Studies, Great Zimbabwe University, Masvingo, P \\ O Box 1235, Zimbabwe. Tel: 263-7-7297-8970. E-mail: marevarugare@gmail.com; shumirai.nyota@gmail.com
}

\author{
Received: July 23, 2012 Accepted: November 8, 2012 Online Published: November 29, 2012 \\ doi:10.5539/ijel.v2n6p112 URL: http://dx.doi.org/10.5539/ijel.v2n6p112
}

\begin{abstract}
This paper explores new developments in Shona lingo, whereby Shona lingo borrows words from mainstream Shona and assigns new meanings to them. The paper examines this adaptation of adoptives at the semantic level. Data were collected through observation, participant observation and a questionnaire. The paper established that Shona lingo borrows different items of grammar as they are from mainstream Shona but attaches new meanings to them. The identified resultant semantic changes include, changes in the ranges of meaning resulting in extension or narrowing the semantic content of the word, radical shift in meaning and changes in emotive value resulting in amelioration or pejorative meanings. The paper also shows how Shona lingo is reflective of the socio-economic situation of the Zimbabwean society.
\end{abstract}

Keywords: adoptives, borrowing, language contact, language variety, semantic change

\section{Introduction}

\subsection{Street Lingo}

According to Poole (1999), street lingo is a language variety that may be spoken when a section of society wishes to reinforce its identity and exclude others. While the social elite may achieve this end by adhering to the standard language, other sections of society may endeavour to achieve the same end by using street lingo or slang, a variety that is so different from the standard, to the uninitiated. Research in the area of urban culture and language in Africa shows how changes in street lingo are part and parcel of the fluidity and mobility of contemporary urban culture ( Veit-Wild, 2009). Mixed languages have been observed to be the norm in the urban cities of Africa South of the Sahara, that is, central, southern, east and western cities of Africa. Examples of well known mixed urban languages include Nouchi (Abidjan), Camfranglais (Yaounde-Douala), Indoubil and Lingala ya Bayankee (Brazzaville and Kinshasa), Iscamto (Johannesburg), Sheng and Engsh (Nairobi), ( Veit-Wild, 2010; Kiessling and Mous, 2004).

In Zimbabwe, Shona street lingo, also called Zimbolicious (Wild, 2009), Shonglish or Shongi because of the mixing of Shona and English, like any other urban language, is a specialized language of a group of people who share a common interest or belong to a similar co-culture. It is spoken mainly by Shona urban youths and middle aged urban imbibers from well- to- do families. The co-culture of this group is commonly known as chidhorobha (the way of the town people) or chisalala (the way of those who eat salads) because they have the money, coming from well- to- do families. These urban youths are commonly referred to as manose or manose brigade (those who speak through the nose) or masalads (those who eat salads). The masalads or manose are from wellto- do families, most of whom live in the sprawling leafy low density suburbs far away from the high density suburbs where the poor live, a set up which is common in all urban centers of Zimbabwe. The current Zimbabwe economic crisis eliminated the middle class as the rich became richer and the poor became poorer. Those from the former middle class, such as teachers and nurses or just civil servants, unless they are involved in corrupt dealings or gone to the diaspora, have joined the poor because they only earn 150US dollars per month. The masalads youth and imbibers use a lingo which gives them an identity emphasizing their class difference and also distinguishing them from the rest of the Zimbabwean youths especially those from the high density suburbs who have their own ghetto lingo and those from the rural areas.

Shona lingo consists of highly informal words or phrases which have been coined or formed by mixing 
languages. Speakers of Shona lingo use it in their informal discussions on any subject matter, especially on topical issues in Zimbabwe, such as politics, socio-economic issues, and HIV and AIDs. The vehicles or channels used to transmit street lingo include e-mails, cell-phone text messages, Shona lingo chat forums and urban groove music.

A lot has been written on Shona lingo's purpose and structure, for example, Mashiri (2002), Veit-Wild (2009), Chikanza and Chiwome (1992). This paper's point of departure is its focus on the observed new trends in lingo terminology creation. The writers of this paper have observed an interesting and new development in Shona lingo, whereby this language variety borrows words from mainstream Shona and ascribes new meanings to them. This was observed in Shona lingo as used by students at great Zimbabwe University (GZU), where the researchers teach Linguistics and Communication Skills. This trend is not peculiar to Shona lingo, however. Pollard (2003) who focuses on the creation of words within the lexicon (wordology) of Dread Talk or the language of the Rastafari, observes that one of the aspects of this wordology is whereby known (English) items bear new meanings. For example, the English word 'chant', which means 'singing' or reciting Psalms, has come to mean 'to discuss' or to talk about religious matters in Dread Talk. In this paper, the researchers explore the change of meaning in Shona lingo adoptives, whereby known Shona linguistic items have new meanings ascribed to them in their new environment of Street lingo.

\subsection{Loan or Borrowed Words}

Loan words, also known as adoptives, are words that have been borrowed from other languages. In this case, Shona lingo as a language variety is borrowing from mainstream Shona. As Fromkin and Rodman (1985:309) state, borrowing occurs when "one language takes a word or a morpheme from another language and adds it to its lexicon". This normally happens as a result of language contact. For instance, for mainstream Shona itself, its adoptives came from other languages within the Bantu group and from the technically dominant European languages, in particular, English, the language of Zimbabwe's colonizer, which became the formal language of Zimbabwe ahead of its indigenous languages such as Shona and Ndebele. The majority of Shona loan words come by way of transliteration, "a process in which loan words are reshaped at the phonological and morphological levels" (Chimhundu, 1979:143). For example, in the following Shona borrowed words from English, chikoro (school) and wacha (wash), their phonological and morphological characteristics have been adapted into the characteristics of the borrowing language, Shona. In this paper, however, the focus is on adaptation of Shona lingo adoptives at the semantic level. It is the concern of this paper to show such adoptives and discuss the new meanings ascribed to them.

\subsection{Change of Meaning (Semantic Change)}

The concept 'change of meaning' or 'semantic change' was introduced into linguistics by Edward Sapir who observes that "...every word, every grammatical element...is slowly changing configuration molded by the invisible and impersonal drift that is the life of a language" (Sapir in Ullman 1977:458). Keith and Shuttleworth (2000:219) observe the same when they assert that "...change is an essential part of life; without change, life ceases. Language too must change, if it is to remain alive. A language that does not change is a dead language." This same view is shared by Crystal (1992:328) who asserts that,

"Languages are always in a state of flux. Change affects the way people speak as inevitably as it does any other area of human life. ... Language would stand still only if society did."

Semantic change occurs when a word is employed to express a meaning that it did not have or express previously. Stern cited in Louwrens et al (1992:49) sees semantic change as the modification of the semantic content of a word. This occurs when a new name becomes attached to a sense and/or a new sense to a name. Change of meaning, therefore, essentially "concerns a shift of relationship between words on the one hand and integral senses on the other hand" (Louwrens et al, 1992:49). In other words, semantic change involves a change in the relationship between the word or sign or signifier on the one hand, and that which is signified, or referent, on the other. The consequences of semantic change are varied and include changes in range of meaning. Change in meaning may be so radically shifted from what the word originally meant including changes in emotive value.

Crystal (1992:330) observes that semantic change is "perhaps the most obvious area of linguistic change... profoundly connected with the life, literature, and culture of a community" and goes on to identify extension, narrowing, shift, figurative use, amelioration and pejorative as the types of semantic change. In extension, the word widens its meaning. In narrowing, a word becomes more specialized in meaning. When a word undergoes a shift in meaning, it moves from one set of circumstances to another. Figurative use involves a shift in meaning based on an analogy or likeness between things. When a word undergoes amelioration, it loses an original sense of disapproval, and finally, pejorative entails a word developing a sense of disproval. Kiessling and Mouse 
(2004:324) observe that there are various types of semantic manipulation when they assert, "Characteristics of youth languages is the farfetched extension or change of the meaning of words with the function of insult, ridicule, exaggeration, or simple enjoyment and play. All kinds of normal semantic processes such as metaphor, metonymy, synecdoche, hyperbole, euphemism and dysphemism are applied but to the extreme."

\section{Methodology}

\subsection{Population and Sample}

The target population for this study was all youths who speak Shona street lingo in Zimbabwe. Great Zimbabwe University students were purposively chosen as the sample because the institution was deemed to be a microcosm of society by virtue of it being made up of young students drawn from different parts of Zimbabwe where Shona street lingo is spoken. As a national institution, Great Zimbabwe University (GZU) attracts staff and students from all over the country. This means that all the major dialects of Shona are represented. In addition to being a national institute, GZU is also centrally located at the intersection of the Harare-Beitbridge and Mutare-Bulawayo highways. As such, it attracts staff and students from eastern Zimbabwe where Manyika, Barwe, Ndau and Hwesa are spoken and from western Zimbabwe where Kalanga and Karanga are spoken. Karanga is also spoken in central Zimbabwe. The institution also attracts staff and students from northern Zimbabwe where Zezuru and Korekore dialects are spoken. The southerners are also attracted but they are of Ndebele origin. Moreover it is mainly the youth from well- to- do families who can afford the exorbitant university fees of more than 500US dollars per semester. Add to that accommodation and subsistence money. This makes the sample representative of Shona speakers and Shona lingo users.

\subsection{Data Collection Tools}

Data were collected through the participant observation and questionnaire techniques.

\subsubsection{Observation}

GZU students were observed for a year, as they went about conversing in their various activities in all spheres of university life, including in lectures, social clubs, sporting, library and dinning hall. The researchers listened to students' conversations, speeches, discussions and jokes and noted how they used Shona words, phrase and expressions as street lingo. The researchers wrote down the words, phrases and expressions.

In some cases the researchers participated, where their identity was not known to the individuals being observed and the researchers interacted with the members of the group as naturally as possible as part of the group (Fraenkel and Wallen, 1990). Such participant observation would take place even in kombis on journeys to town and to the university. In other cases, the researchers were complete observers, whereby they observed the activities of a group without actually participating in those activities (Fraenkel and Wallen, 1990).

\subsubsection{Questionnaire}

A structured questionnaire was distributed to a sample of 400 students who were randomly selected from each of the four faculties at GZU (100 from each faculty) of education, Arts, Commerce and Sciences. The questionnaire contained a list of the Shona words which the researchers had discovered were being used in street lingo by students. Students were requested to supply the street lingo meanings of each of these words.

\section{Results}

This section presents the results of the study which are summarised in tabular form. 
Table 1. Shona words that have assumed new meaning in street lingo

\begin{tabular}{|c|c|c|}
\hline Shona Word & Original Meaning(s) & New Meaning(s) \\
\hline \multirow[t]{4}{*}{ - Kumhanya } & To run & To rush \\
\hline & & To date each other in an illicit love affair \\
\hline & & To sell fast \\
\hline & & To rush and make uninformed decisions \\
\hline \multirow[t]{2}{*}{ - Makeke } & Cakes & Anything good looking, such as success, girl \\
\hline & & Anything tasting delicious \\
\hline - Kudzvanya & To press & To be difficult, ie life \\
\hline - Kukoromora & To destroy or disturb order & To commit a crime \\
\hline - Kunyura & To sink & To suffer a loss eg of profit \\
\hline - Kukava & To kick & To be expensive \\
\hline - Kukanya & To mix thoroughly & To err/to betray \\
\hline - Chirungu & It's English & Its ok/fine \\
\hline - Chingwa & Bread & Something profitable, good pay \\
\hline - Chibhanzi & Small bun & Money/cash \\
\hline - Dovi & Peanut butter & Something profitable, good pay \\
\hline - Kumama & To defacate & To suffer loss, to lose a game \\
\hline - Kunyorwa & To be written & To find a test/exam very difficult \\
\hline - Mbishi & Raw/uncooked, not well cooked & Brand new car \\
\hline - Waya & A piece of wire & A hundred dollar note \\
\hline - Gwavha & A guava (fruit) & A fake note of money \\
\hline - Chitunha & A corpse & A marked assignment/project for one to just copy from \\
\hline - Kupiwa & To be given & To remember something \\
\hline - Kubikwa/Kukangwa & To be cooked, to be fried & To be lied to, to be defeated \\
\hline - Kusasa & To sprinkle & To tell \\
\hline - Kubatisa & To make someone keep something & To tell \\
\hline - Vhiri & A wheel & A good car \\
\hline - Simbi & A piece of metal & A beautiful girl \\
\hline - Mbama & Slap on the face & A beautiful girl \\
\hline - Bango & A $\log /$ a pole & A good car \\
\hline - Mudhara & Old man & Father \\
\hline - Dhara & Old man & An expert, a rich man \\
\hline - Muchembere & Old woman & Mother \\
\hline - Chidhinha & Brick & Old model/big cellphone \\
\hline - Bhara & Wheelbarrow & Old decrepit vehicle \\
\hline - Nyoro & Wet/damp/moist & Unprotected sex \\
\hline - Kubaya & To stab & To go \\
\hline - Reza & Razor blade & Promiscuous man \\
\hline - Mhene & Gazelle & Rich man \\
\hline - Kubatana & To be intact & To be well-shaped (of a woman) \\
\hline - Kudhakwa & To be drunk & To be unexciting, dull, faulty, disorderly \\
\hline
\end{tabular}




\begin{tabular}{|c|c|c|}
\hline - Kuwanza & To supply too much of the required & To mock \\
\hline - Bundo & Grass & Marijuana (mbanje) \\
\hline - Vahombe & Big & A rich person, an expert \\
\hline - Kununa & To be invitingly ripe & To be well shaped (of a lady) \\
\hline - Mboko & Pumpkin & A foolish person \\
\hline - Kukwata & To boil (of sadza) & To fear/to suffer \\
\hline - Kudya & To eat & To enjoy good life \\
\hline - Nyoka & Snake & A worn-out tyre \\
\hline - Moto & Fire & Challenges/ trouble \\
\hline - Kudhibha & To dip (of cattle in a dip tank) & To be confused/to fail to remember \\
\hline - Kutyora & To break & To take it easy \\
\hline - Mazino & Teeth & Difficult conditions \\
\hline - Panyanga & On the horns & On position of highest authority or control \\
\hline - Matsotsi & Tricksters, conmen, thieves, robbers & HIV and AIDs \\
\hline - Ndeipi & Which one is it & Hello/how are you? \\
\hline - Ndokubata & I will touch you & See you later/phone you later \\
\hline - Kufamba & To walk/ To travel & To go on well (of life, of progress) \\
\hline - Hausundi & You will not push & You will not defeat \\
\hline - Kukupa dhamhu & To scoop all the water from a dam & To accomplish a great task \\
\hline - Kupenda nyoka & To paint a snake & To accomplish a great task \\
\hline - Kukorobha njanji & To mop a railway line & To accomplish a great task \\
\hline - Kambada & Small leopard & Sleek car \\
\hline - Mhata & Anus & A stupid, foolish person \\
\hline
\end{tabular}

Table 1 shows that the recorded Shona lingo adoptives have undergone changes in meaning. Some Shona lingo adoptives have undergone change of meaning in their ranges of meaning, some in emotive overtones and yet some, adoptives, show radical shifts in their meanings. These changes in meaning are discussed below.

\section{Discussion}

\subsection{Lingo Adoptives Showing Semantic Changes in Range of Meaning}

Some adoptives have undergone changes in range of meaning. Such changes can result in specialization or generalization of meaning. When the concept, range of meaning is applied to semantic changes, the range or scope of a semantic item may be restricted or widened, as Fromkin and Rodman (1988:31) point out, "the meaning of semantic representation of words may change becoming broader or narrower." Many Shona lingo adoptives have for a variety of reasons widened or narrowed their range of meaning. Narrowing results from specialization.

Specialization of meaning results in a word having its scope of meaning restricted. Its most frequent cause is said to be "specialization of meaning in a particular social group" (Ullman, 1977:483). For example the Shona lingo chimbuya (stout granny or maternal aunt) has undergone changes in meaning resulting in specialization of meaning. In Shona lingo the term chimbuya is used by young university students to refer to a senior lady student, especially, one studying the Bachelor of Education Primary (In Service) degree programme. When the youthful students use the term, they will be mocking the senior students. It would appear the youths use it to stress upon and remind the elderly students of the generation gap between themselves and the youths.

In mainstream Shona, the word chimbuya is a noun in Class 7 with a secondary noun prefix chi- which is commentary. Secondary prefixes indicate special or abnormal specimens of the item referred to (Fortune 1984). As a special specimen, the word chi-mbuya could be a term of endearment referring to a well structured old grandmother or maternal aunt of good character. When indicating the abnormal specimen, the commentary secondary prefix carry overtones of sarcasm, criticism and caricature as it makes its implied comment on an 
item's or referent's size or quality. As a word with a commentary secondary prefix chi- the term chimbuya refers to a (fat, stout, dirty, careless, jolly old lady). The meaning of the term chimbuya can best be understood with the word mbuya in mind. Te term refers to (grandmother or maternal aunt-one's maternal uncle' wife). The reason for the restriction in meaning in the Shona lingo adoptive, chimbuya, is thus due to specialization of meaning in that Shona lingo social group. It is possible the youthful students feel threatened when competing in class with the elderly lady students. They cope with such challenges by using or coining derogatory insulting terms of ridicule such as chimbuya or zvimbuya (plural). Thus the change of meaning in the term chimbuya came about through semantic manipulation with the function of insult and ridicule on the part of the youths. The term also smacks of insensitivity to gender since there is no equivalent lingo term for male elderly students. It is, however, not surprising that there is no male term equivalent for chimbuya, the Shona society being a patriarchal one.

The other Shona lingo adoptives that have undergone specialized change in meanings include the terms Harare North and Harare South. In mainstream Shona, the term Harare North refers to Harare's low density suburbs leafy which are located in the northern part of the city such as Mt Pleasant, Vainona and Borrowdale. These are the suburbs where the wealthy Zimbabwean people live. During the economic crisis some people fled the country and went to live in London. And because of the strength of the British pound versus the Zimbabwean dollar, those people developed properties in these low density areas and by comparison and metaphoric extension, London was named Harare North in Shona lingo. On the other hand, Harare South refers to the southern part of Harare where the high density suburbs are located. While some people went to London during the crisis many more went to South Africa where because of its proximity to Zimbabwe some people even went there as illegal immigrants in large numbers resembling the large numbers of people found in the high density suburbs in Harare south hence in Shona lingo, South Africa became known as Harare South. Thus the change of meaning in these two terms came about through semantic manipulation of metaphorical extension and onomastic synecdoche.

On the other hand, generalization of meaning takes place "when the meaning of a word becomes broader, when that word means everything it used to mean and then some more (Fromkin and Rodman 1988: 313). Generalisation of meaning can therefore be taken as the opposite of specialization or restriction of meaning. The word will be applied to a wider variety of things but its intention will decrease. This means that it will tell us little about the referent. The Shona term korokoza (illegal gold panning) was coined when some Zimbabweans, makorokoza (illegal gold panners) practiced that panning in and around gold mines. The makorokoza did so without proper gold mining instruments but scraped the ground with hand tools. The word korokoza was coined from the sound metaphor of scrapping the ground for gold. During the Zimbabwe economic crisis of the millennium that intensified between 2006 and 2008, even the professionals including all civil servants from all government departments left their jobs which were no longer paying due to the hyper inflation experienced and began to survive by any means necessary such as self proclaimed taxi and bus rank marshaling, cross boarder trading, forex dealing etc. In Shona lingo that means of survival is termed kukorokoza and the practioners are termed makorokoza. Thus in Shona lingo, the connection between korokoza and illegal gold panning disappeared, that is, the meaning of the word impoverished since the word lost a distinctive trait. In other words extension of meaning leads to a wider and therefore, a less specific range of meaning.

Similarly, the Shona adoptive mupositori from 'the Apostle' refers to particular sects of apostles, the ones whose members shave their heads clean and wear long white robes such as Madzibaba, Johanne Marange and Johhane weChishanu. This is despite the fact that there are other apostolic faith sects in Zimbabwe such as AFM, ZAOGA and others. The reason for the restriction could be the close resemblance of the members of these vapositori groups to the pictures of those apostles of biblical Acts of the Apostles such as Peter and Paul. As a Shona lingo adoptive, the term means more than the meanings indicated above. In the Shona lingo speech community, the term also refers to anybody whose head is clean shaven and to those who grow a long beard, a practice which is very common among the urban youths.

\subsection{Examples of Shona Lingo Adoptives Showing Radical Shifts in Meaning}

As already shown changes in meaning may be so radically shifted from what the word originally meant "that only a meager semantic relationship between the original word and the loan word can be observed", (Louwrens et al 1992:162). For instance, the Shona lingo adoptive makeke from cakes refer to anything nice be it a thing, situation, positive attitude or breakthrough. In mainstream Shona keke refers to a mixture of flour, butter, eggs, sugar and other ingredients baked in an oven and then iced and decorated.

The term kudzvanya (to press hard) is another example of a Shona lingo adoptive showing a radical shift. In Shona lingo kudzvanya is a verb showing that a thing or situation is difficult. Examples of such situations include an illness, poverty or any crisis. On the other hand the Shona verb kudzvanya means to press hard or to trap 
something between two hard surfaces in such a way that the trapped thing finds it very hard to wriggle out. The meanings of the term kudzvanya as used in mainstream Shona and Shona lingo show the radical shift in meaning which the term has undergone with its use in Shona lingo.

\subsection{Changes in Emotive Value: Amelioration/Pejorative Developments}

Some Shona lingo adoptives have undergone emotive changes in emotive meaning. Emotive meaning is also called affective meaning by some semanticists such as Leech (1975). This meaning reflects "the personal feelings of the speaker including... his attitude to something he is talking about" (Leech 1975:18). Borrowing may cause a shift in the emotive value a word has in its language of origin on the one hand and in the borrowing language on the other. This change may take place in a depreciative manner, 'pejorative', as in the semantic change between reza (razor blade) and reza (promiscuous man who indulges in illicit sexual encounters) as a Shona lingo adoptive.

Euphemism has been found to be the motive source behind many pejorative developments. In the example of reza given above, it would appear as used in Shona lingo, is used as a euphemism for the Shona bad word hure rechirume (a male whore). It would also appear the term reza as used in Shona lingo as the substitute for hure rechirume has ceased to be felt as such but has become directly associated with the idea it was designed to veil. This has resulted in a depreciation of the adoptive reza. The other example of a Shona lingo adoptive showing pejorative developments is the term nyoro (wet, damp, moist). When used in Shona lingo, nyoro refers to unprotected sex.

The change in the emotive value of words may also take place in an appreciative manner, 'ameliorative', Barber (1982: 253) asserts that amelioration is often the result of a general change in social or cultural attitudes". The term kumama (to defecate) is highly offensive such that it is often replaced by the Shona adoptive kudhota from the English word 'dot' which is used euphemistically. The Shona lingo social or cultural attitude is different from that of the mainstream Shona. The term kumama as used in Shona lingo means to suffer loss. This meaning is not offensive as that of kumama in mainstream Shona. Thus, the adoptive kumama's change in emotive value has taken place in an emotive value.

\subsection{Preoccupations of Shona lingo}

An examination of the list of lingo adoptives above shows that some aspects are overlexicalized and it also appears that this overlexicalization is not by accident but by design. The overlexicalised lexical items are reflective of the socio-economic set up of the Zimbabwean society. These aspects include girls, cars and money and hardships. Quite a number of adoptives shows a preoccupation about women by the users of Shona lingo. Some of the adoptives used for lady/girl in Shona lingo include, makeke, simbi, mbama, kubatana and kununa. These terms apart from showing overlexicalization, their change of meanings also show predictable connotations. One telling example is kununa (to be invitingly ripe especially of the dohwe 'a very sweet Zimbabwean wild fruit which when ripe looks like it is dripping of sugar' in mainstream Shona) while in lingo its referent is a well shaped and beautiful lady, a meaning which displays sexual connotations. The other adoptive with a suggestive new meaning is kubatana which simply means (to be intact or glued together) in mainstream Shona while in lingo it refers to a well-shaped lady/girl/woman. One is tempted to see Shona lingo as a male's language.

Several other words in the list refer to money/salary/pay/riches and buying and selling. Examples that show a preoccupation with money are chingwa, chibhanzi, dovi, waya, gwavha, dhara, mhene, vahombe. Kumhanya, kunyura, kukava, kumama are all about buying and selling. The referent car is also overlexicalized. Some of the words for car in Shona lingo include mbishi, vhiri and bango. These lexical items show an obsession and insatiable appetite with material possessions, something which is typical of masalads, though out of step with Shona tradition. For the masalads, a car is not just a means of transport, but a status symbol. It must not just be an ordinary or old car, bhara, but a brand new car, mbishi or a sleek one, kambada. The masalads also like to show off their material possessions and one way of doing this is by dating malads girls who also have a big appetite for good things as is observed by Chuma (2002) cited in Veit-Wild (2009:687):

Dating a female masalad is one of the most daunting tasks for young Zimbabwean men. These sophisticated young women will demand virtually everything from the prospective lover: cash, clothing, expensive takeout food, payment of cell-phone bills. In fact the tacit minimum qualification to date a bona fide musalad is the so-called 3Cs: car, cell-phone and cash.

Words for hardships are also many as is shown by kudzvanya, moto, kukwata, mazino, hausundi, kukupa dhamhu, kupenda nyoka, kukorobha njanji. These are reflective of the harsh socio-economic situation of Zimbabwe. Many people are forced into small business development enterprises such as basketry, flea markets and cross 
boarder trading, buying and selling wares from South Africa. Some sell artifacts in South Africa so that they get the South African Rands which they in turn use to buy goods for resell back in Zimbabwe. The above words reflecting harsh conditions are used by the lingo users to describe situations where money is hard to come by such as when deals fail to bring in lots of money.

\section{Conclusion}

A lot has been written on Shona lingo or Shona urban language. This paper also concerns itself with Shona lingo but its point of departure is its focus on the new linguistic innovative development in Shona lingo whereby Shona lingo borrows Shona words as they are but ascribes new meanings to them in their new environment. The discussion showed how the Shona lingo adoptives undergo semantic changes which essentially concern a shift of relationships between the words on one hand and the sense on the other. This semantic change is inevitable since these adoptives are now used to express meanings that they did not express previously. The changes in meaning found in these adoptives are varied. Some Shona lingo adoptives have undergone change of meaning in their ranges of meaning resulting in specialization or generalization of their semantic scope. Some have undergone semantic shifts in emotive overtones. While in some adoptives this change has taken place in a depreciative manner 'pejorative', in some of the adoptives it has taken place in an appreciative manner, 'ameliorative'. The data gathered also showed some of the adoptives, show radical shifts in their meanings. The paper also showed that there are some areas or aspects of life that the lingo users overlexicalize in their adoptives and these reflect some preoccupations of the lingo users and the socio-economic set up of Zimbabwe.

\section{Acknowledgements}

The researchers would like to sincerely thank the four hundred Great Zimbabwe University students who participated in the study by sacrificing their valuable time to complete the questionnaire administered to them. Without their support and co-operation, the study would not have been possible.

\section{References}

Barber, L. (1982). The Story of Language. Suffolk: Richard Clag.

Chimhundu, H. (1979). Some problems relating to the incorporation of loan-words in the Lexicon. Zambezia, $11(1)$.

Chiwome, E., \& Chikanza, J. (1992). Sociolinguistics and Education: A survey concerning attitudes on the teaching of Shona through the medium of Shona and English. In R. K. Herbert (Ed.), Language and society in Africa: The Theory and Practice of Sociolinguistics. Johannesburg: Witwatersrand University Press.

Fromkin, V., \& Rodman, R. (1988). An Introduction to Language. New York: Holt Rinehart.

Keith, G., \& Shuttleworth, J. (2000). Living Language. London: Hodder and Stoughton.

Kiessling, R., \& Mouse, M. (2004). Urban Youth Languages in Africa. Anthropological Linguistics, 46(3).

Leech, G. (1975). Semantics. London: Hazel and Watson.

Louwrens, L. J. et al. (1992). Only Study Guide for SEMANO-T (revised ed.). Pretoria: UNISA.

Makoni, S. et al. (Eds.) (2003). Black Linguistics. Language, Society and Politics in Africa and the Americas. London: Routledge.

Mashiri, P. (2002). Code-Mixing in the Speech of Students. Southern African Linguistics and Applied Language Studies, 20(4). http://dx.doi.org/10.2989/16073610209486314

Pearson, J. C. et al. (2003). Human Communication. New York: McGraw Hill.

Pollard, V. (2003). Sound and Power: The Language of the Rastafari. In S. Makoni et al. (Eds.), Black Linguistics. Language, Society and Politics in Africa and the Americas. London: Routledge.

Poole, S. C. (1999). An Introduction to Communication. New York: Pelgrave.

Ullman, S. (1977). Change of Meaning. In H. Hungerford et al., English Linguistics. Illinois: Scott, Foresman and Company.

Veit-Wild, F. (2009). 'Zimbolicious' The Creative Potential of Linguistic Innovation: The Case of Shona-English in Zimbabwe. Journal of Southern African Studies, 35(3). http://dx.doi.org/10.1080/03057070903101896 